\title{
Effect of Reward on Employee Performance: A Case of Kenya Power and Lighting Company Ltd., Nakuru, Kenya
}

\author{
W. L. Njanja ${ }^{1}$, R. N. Maina ${ }^{1}$, L. K. Kibet ${ }^{1} \&$ Kageni Njagi $^{1}$ \\ ${ }^{1}$ Faculty of Commerce, Kabarak University, Kenya \\ Correspondence: W. L. Njanja, Faculty of Commerce, Kabarak University, Kenya. E-mail: \\ lnjanja@kabarak.ac.ke
}

Received: October 9, 2012

Accepted: September 25, 2013

Online Published: October 15, 2013

doi:10.5539/ijbm.v8n21p41

URL: http://dx.doi.org/10.5539/ijbm.v8n21p41

\begin{abstract}
Today's organizations are operating in a very dynamic and highly competitive environment. To remain relevant in the market, they have to be able to respond quickly to ever changing customer demands. Reward management is one of the ways used by organizations for attracting and retaining suitable employees as well as facilitating them to improve their performance. KPLC is an organization that offers essential energy services that support other sectors of the economy. The management has established rewards in their organization in pursuit of increasing employee performance so as to ensure prompt and quality service. However, the extent to which the rewards adopted at KPLC have influenced employee performance is not established. This study therefore aimed at determining the effect of reward on employee performance at KPLC. Specifically the study sought to determine the effect of cash bonus on employee performance. The research adopted correlation research design. 68 management employees responded. Data was collected using questionnaires. Descriptive statistics (frequency tables, percentages) were used to present data. Inferential statistics (chi-square) was used to analyze the relationship between cash bonuses and employee performance. Data was analyzed with the help of the Statistical Package for Social Sciences (SPSS) computer programme. The findingsof the study showed that cash bonus have no effect on employee performance $(\mathrm{p}=0.8)$. This is because those who received cash bonuses and those who did not all agree that the cash bonus affects their performance the same. The organization should focus on changing the intrinsic nature and content of jobs. This will increase employee motivation as employees will get more autonomy more challenging job assignments and responsibilities. Further research can be done to find out impact of other rewards on performance e.g. owning equity. Research can also be done to identify other factors which may affect performance. Such findings can enhance management of performance.
\end{abstract}

Keywords: reward, cash bonuses, reward management, dynamic competitive environment, employee motivation, employee performance, Kenya power and lighting company ltd

\section{Introduction}

\subsection{Background to the Study}

Reward management is one of the strategies used by Human Resource Managers for attracting and retaining suitable employees as well as facilitating them to improve their performance through motivation and to comply with employment legislation and regulation. As a result of these pressures, HR managers seek to design reward structures that facilitate the organizations strategic goals and the goals of individual employees. Reward systems are very crucial for an organization (Maund, 2001). Rewards include systems, programs and practices that influence the actions of people. The purpose of reward systems is to provide a systematic way to deliver positive consequences. Fundamental purpose is to provide positive consequences for contributions to desired performance (Wilson, 2003). The only way employees will fulfil the employers dream is to share in their dream (Kotelnikov, 2010). Reward systems are the mechanisms that make this happen. They can include awards and other forms of recognition, promotions, reassignments, non monetary bonuses like vacations or a simple thank-you.

When employees are rewarded, they get work done. Employers get more of the behaviour they reward, not what they assume they will automatically get from employees. Thus when employees surpass their target or exceed their standard they should be rewarded immediately as a way of motivating them. By doing this, employees directly connect the reward with behaviour and higher performance they have attained. Effective reward systems should always focus on the positive reinforcement. Positive reinforcement encourages the desired behaviour in 
organizations. This encourages employees to take positive actions leading to rewards. Reward programs should be properly designed in the organization so as to reinforce positive behaviour which leads to performance (Torrington \& Hall, 2006).

An organization for global manufacturer of brand-name products for consumers needed to improve levels of employee motivation fast in order to improve performance. Managers focused on 'recognition' as the key to raising employee morale. Every employee could nominate anyone they considered worthy of recognition. Successful employees got certificates and they really felt appreciated. In the experience of a 'recognised' employee "to be recognised formally gave me extra motivation and made me wonder what $i$ could do to keep the momentum going" (Gyurcik \& Brawley, 2000).

Scottrade Inc.; a firm that deals with financial services delivered superior performance and took care of its employees even in the turbulent environment that had gripped the entire financial services industry. The firm had given good performance and industry observers felt that its performance management and reward system was responsible for this (Purkayastha \& Chaudhari, 2011).

Kenya Power and Lighting Company Ltd Company transmit, distribute and retail electricity throughout Kenya. The Government of Kenya is the major shareholder, while the rest is owned by private shareholders. KPLC Ltd. is divided into four administrative regions which are Nairobi, Coast, Mount Kenya and Western and it has many branches country wide. The research will be carried out at KPLC Nakuru main office, which is the Central Rift Sub Region headquarters.

\subsection{Statement of the Problem}

Reward management is one of the strategies used in organizations to improve organizational performance. Researchers, practitioners and scholars have established that there is a positive link between reward management and desired performance. KPLC is an organization that offers essential energy services that support other sectors of the economy. The management has established rewards in their organization; these include cash bonuses in pursuit of increasing employee performance so as to ensure prompt and quality service. However, the extent to which cash bonuses influence employee performance is not established. This study therefore aimed at determining the effect of cash bonuses on employee performance at KPLC.

\section{Literature Review}

\subsection{Designing Effective Reward Policies}

The task of developing a strategic rewards framework for organizations is usually challenging but necessary to survive in the competitive and changing market place. The process however cannot be copied from the organizations but needs to be designed, developed and grown within the unique environment of the organization (Wilson, 2003). A well designed incentive program rewards measurable changes in behaviour that contribute to clearly defined goals. The challenge in developing such a program lies in determining what rewards are effective agents of change, what behaviours can be changed and the cost and benefits of eliciting change (Hartman et al, 1994).

Employees should be aware of the relationship between how they perform and the rewards they get. Organizations should apply performance management programs which assist in planning employee performance, monitor performance by effecting proper measuring tools Rewards should be used as a way of strengthening good behaviour among employees as well as productivity. Hence reward systems should focus on reinforcing positive behaviour. Employees could be rewarded for working overtime, taking initiative, team work, reliability, exceptional attendance, outstanding customer feedback, meeting deadlines or timeliness, productivity etc. Employers and managers should then design or come up with a system to measure or quantify all these aspects so that rewards are then given accordingly.

A good reward system that focuses on rewarding employees and their teams will serve as a driving force for employees to have higher performance hence end up accomplishing the organizational goals and objectives.

An effective reward program may have three components: immediate, short-term and long term. This means immediate recognition of a good performance, short- term rewards for performance could be offered monthly or quarterly and long- term rewards are given for showing loyalty over the years (Schoeffler, 2005). Immediate rewards are given to employees repetitively so that they can be aware of their outstanding performance. Immediate rewards include being praised by an immediate supervisor or it could be a tangible reward. Short term rewards are made either monthly or quarterly basis depending on performance. Examples of such rewards include cash benefits or special gifts for exceptional performance. 
Rewarding should not only be applied to individual employees within the organization but also to teams that perform excellently. Incentives given for good behaviour usually improve the relationship between the employees and management because employees feel that they are being appreciated for their efforts and good work. This leads to increased employee morale, better customer care as well as increased productivity.

Long-term rewards are awarded to employees who have been performing well. Such an employee will become loyal to his or her organization and it reduces employee turnover. Long term rewards include being made partner, or cash benefits that mature after many years of service or at retirement. These rewards are very strategic for retaining the best human resources (Yokoyama, 2010).

For rewards to be effective, they have to be seen as fair. This means there has to be openness with respect to information about how the reward system operates and how employees will be rewarded. Employees should also be involved in designing the reward system and its administration (Jenkins, 1992).

\subsection{Reward Systems}

Every organization's reward system should focus on these major areas; compensation, benefits, recognition and appreciation (Sarvadi, 2010). Benefits such as car loans, medical covers, club membership, ample office space, parking slots and company cars are ways of rewarding and employees do note the types of benefit that their organization offers.

Recognition and appreciation are another integral component of a winning strategic reward system. Recognition is to acknowledge someone before their peers for desired behaviour or even for accomplishments achieved, actions taken or having a positive attitude. Appreciation on the other hand centres on showing gratitude to an employee for his or her action. Such rewards help employees to gauge their performance and know whether they are doing good or bad (Sarvadi, 2010).

\subsubsection{Cash Bonus}

Cash bonus is another form of reward that organizations use to reward employees for exemplary performance that is if they have performed higher or exceed their set targets, this hence makes them eligible (Finkle, 2011). The amount of cash is determined by how high the employee has over exceeded the set targets or they can also be based on ranks or job groups. Nowadays, companies are rewarding performance bonuses to junior employees to increase output, unlike the past where they used to be a privilege of top executives. Performance bonuses are now on the rise in many organizations because managers want to link performance to reward. (Block \& Lagasse, 1997).

Companies use cash bonuses to reward their employees' performance during the year under appraisal. But there is also the unspoken expectation that these bonuses will be a factor in motivating employees' performance next year as well. Employees who receive a large bonus will likely want to get it next year too. On the other hand, employees who receive a miserly bonus and it reflects how the company assessed their performance, might consider improving next year (Finkle, 2011).

\subsection{Theoretical Foundation}

Rewards have been shown to motivate performance when certain conditions exist (Blinder, 1990). Individuals are best motivated when they believe that the behaviour will lead to certain outcomes that are attractive and that performance at a desired level is possible. Motivation therefore best explains element of reward and the effect it has on performance. This study will be based on the following motivational theory.

\subsubsection{Vroom's Expectancy Theory}

Vroom suggested that individuals will choose behaviours they believe will result in the achievement of specific outcomes they value. In deciding how much effort to put into work behaviour, individual are likely to consider three things; valence, instrumentality and expectancy.

All these factors are often referred to as 'VIE' and they are considered to influence motivation in a combined manner. Managers should therefore attempt to ensure their employees that increased effort will lead to higher performance which will hence lead to valued rewards (Ryan \& Pointon, 2005).

The relevance of this theory to the study is that KPLC has put up rewards (cash bonuses) that are supposed to be attractive so as to achieve a desired outcome which is employee performance. Thus employees have to exert effort in their work that will lead to a certain level of performance that is desirable by management, which will then result to a reward. 


\subsection{Performance}

Measuring performance is of great importance to an incentive plan because it communicates the importance of established organizational goals. "What gets measured and rewarded gets attention" (Bohlander et al, 2001).

In discipline of human resource management, different writers suggest the following indicators for measuring employee performance and they include: quality that can be measured by percentage of work output that must be redone or is rejected; Customer satisfaction that can be measured by the number of royal customers and customer feedback. Also, timeliness, measured in terms of how fast work is performed by the employee when given a certain task; absenteeism/tardiness observed when employees absent themselves from work; and achievement of objectives measured when an employee has surpassed his/her set targets, he/she is then considered to have performed well to achieve objectives (Hakala, 2008; Armstrong, 2006).

The management of individual performance within organizations has traditionally centred on assessing performance and allocating reward, with effective performance seen as the result of the interaction between individual ability and motivation. It is increasingly being recognized that planning and an enabling environment have a critical effect on individual performance, with performance goals and standards, appropriate resources, guidance and support from the managers all being central (Torrington, Hall \& Stephen, 2008).

Human resource policies and practices indeed do affect organizational as well as individual performance. Job satisfaction for example, has for a long time been seen as key to affecting business performance as well as commitment. In addition researchers have also identified motivation as the mediating mechanism and some identify trust and morale. In spite of more recent attention to commitment, motivation is still considered to be an important influence to performance (Torrington et al, 2008).

\subsection{Relationship between Rewards and Performance}

Rewards can be used to improve performance by setting targets in relation to the work given e.g. surpassing some sales targets. When the employee surpasses their target, he or she can be given an additional amount to their salary; this will make them strive to achieve more (Maund, 2001).

Research has proven that when human being are appreciated and praised they tend to improve their performance. This is another way an organization can apply as a reward so as to improve performance. Praise could be shown in the organization newsletter or in meetings. When managers take time to meet and recognize employees who have performed well, it plays a big role in enhancing employees' performance (Torrington \& Hall, 2006).

Organizations should reward employees more often. This greatly improves performance compared to having the rewards maybe only once a year. This is because frequent rewards are easily linked to the performance. (Thomson \& Rampton, 2003).

Another way through which organizations can use reward systems to increase output is by personalizing the reward. When rewards tend to be so general, employees do not value them. Organizations can use rewards to improve employee performance by incorporating appraisal or promotion for employees who have a good record of performance. Managers should be on the look out for employees who perform well.

\subsection{Empirical Research}

Ahmed \& Ali (2008) carried out a research on the "impact of reward and recognition programs on employee motivation and satisfaction". Research design used was exploratory. Sample chosen for the study was 80 employees of Unilever companies and data collection instrument used was a questionnaire. Pearson's correlation was used to analyze data to determine the degree of relationship between reward and satisfaction and motivation. Major findings indicated a positive relationship between rewards and work satisfaction as well as motivation. Factors affecting satisfaction were identified; payment $86 \%$, promotion $74 \%$, work conditions $61 \%$, personal $37 \%$. Analysis showed support for a positive relationship between reward and employee satisfaction. The researchers recommended that further studies can be done on 'impact of reward and recognition on motivation and satisfaction for diverse groups of people' example gender, race and disability.

Duberg \& Mollen (2010) undertook a study on reward systems within the health and geriatric care sector. The problem of the study was how reward systems designed in health and geriatric care are and whether the current reward systems affect the care quality. The thesis aimed to extend the knowledge of reward systems in health and geriatric care and know how these systems are designed and what their effects on quality of health and geriatric care are. The methodology took a qualitative approach and interviewed a sample of six leaders in both private and public organizations. Two of the leaders worked in geriatric care and four in health care. The theoretical framework was based on scientific literature about motivation and reward systems. Also literature specifically 
about wage conditions in the health care sector and the public sector was used. Findings showed that salary is an important aspect in the reward system; however other incentives like bonuses and shares were seen to generate an enjoyable work place and happy workers than motivate employees to be more efficient. Results showed that conditions for working with reward systems in the public sector are limited due to the lack of resources and complex large organisation structures with old traditions. This must be reconsidered to be able to work with well designed reward systems similar to those in private care organizations. The researcher recommended that further studies should be done to compare reward system and investigate its impact on an organization in relation with one that does not.

Axelsson \& Bokedal (2009) did a study on rewards - motivating different generations at Volvo Car Corporation. The thesis was based on a case study of Volvo Car Corporation in Göteborg. Empirical data was based on twenty interviews with managers at the company. Major findings showed that challenging work and non-monetary rewards motivate managers, bonuses and shares are not very motivating. Titles are not motivational at all. However, opportunities for growth are motivating for both generations. It was concluded that there exists generational differences. However, both generations considered salary as important and non-monetary rewards to be of great importance. The authors recommended research to be carried out on reward systems and how they impact on other interesting aspects like gender, life stage.

Garlick (2009) carried out an online study of 1913 full-time employees and asked people to rank order 14 potential performance incentives in order of preference. These performance incentives included common extrinsic rewards such as cash bonuses, gift cards, award points, and travel awards, as well as intrinsic rewards such as having more freedom and autonomy at work, being able to choose interesting projects, and being assigned to mentor other employees. Not surprisingly, cash bonuses were listed as the most preferred incentive by three-out-of-four people (74\%) surveyed. Nine-out-of-ten (89\%) listed cash bonuses within their top three preferences. However, the primary issue the study investigated was whether offering cash bonuses really influenced employee attitudes, as well as other business outcomes. The results showed that offering a cash bonus exclusively does not seem to make much of an impact on performance, despite the fact cash bonuses are nearly everyone's preferred reward. While cash bonuses are the most preferred reward for three-out-of-four, and among the top three rewards for nine-out-of-ten, those who only receive a cash bonus are just slightly more satisfied than those who get no reward at all. Furthermore, offering exclusively cash bonuses only seems to have very little impact on company performance, either in terms of increased customer service, or in increased profitability.

The above studies have dealt with reward in organizations and its relationship with factors such as employee motivation, employee performance, employee satisfaction and effect on quality of work done. Overall the studies show reward to have a positive effect. However, different rewards seem to have a different impact on employee attitude, satisfaction and performance. There are mixed findings when it comes to individual rewards and their effect on performance.

\section{Research Methodology}

\subsection{Research Design}

In this study, correlation research design was used; a case study of KPLC. This design includes analysing the relationship between reward and employee performance. The researcher sought to establish whether cash bonuses applied at KPLC have any effect on employee performance.

\subsection{Target Population}

The study population included management employees of Kenya Power and Lighting Company in Nakuru main office who had a total population of 84 employees. A census study was used.

\subsection{Data Collection and Research Instruments}

Questionnaires for management employees were designed based on the study objectives so as to provide in depth information for the study. The researcher obtained an authorization letter from the Faculty of Commerce, Egerton University. The questionnaires were issued to 84 respondents comprising management staff. The respondents were then given two weeks to complete the questionnaire.

\subsection{Validity and Reliability}

Validity is the extent to which the instrument collects data that it is meant to collect. It is the degree to which results obtained from the analysis of the data actually represent the phenomenon under study. In this study, ensuring validity of the data collection instrument involved going through the questionnaire in relation to the set objectives and making sure that it contains all the information that can enable answer these objectives. Reliability 
measures the degree to which a research instrument yields consistent results or data after repeated trials. To ensure reliability, the questionnaire was pre-tested on 20 respondents at KPLC Molo office. In this study a reliability co-efficient (Alpha value) of more than 0.7 was assumed to reflect the acceptable reliability. The objective of pre-testing was to allow for modifications of various questions in order to rephrase, clarify and clear up any shortcomings in the questionnaire.

\subsection{Data Analysis and Presentation}

Data from the proposed research was coded, processed and analyzed using computer based statistical package for social sciences (SPSS). Chi-Square was used to establish the relationship between two variables both of which are categorical in nature. Specifically, it sought to establish degree to which cash bonuses influence employee performance.

Contingency table was used to analyze and record the relationship between two or more variables which are categorical. Descriptive statistics in form of frequencies, percentages, mean, were used to present data.

\section{Results and Discussions}

Out of the questionnaires issued, the researcher got back 68 from management staff.

\subsection{Effect of Cash Bonuses on Employee Performance}

The study sought to find out the perception of respondents as to whether cash bonuses motivate them to perform better. The results are presented in table 1 below.

Table 1. Frequencies of effect of cash bonuses on performance

\begin{tabular}{lcccccccccc}
\hline & $\begin{array}{c}\text { To attend work } \\
\text { regularly }\end{array}$ & \multicolumn{2}{c}{$\begin{array}{c}\text { To work hard to achieve } \\
\text { targets }\end{array}$} & \multicolumn{2}{c}{ To be timely } & \multicolumn{2}{c}{ To do quality work } & \multicolumn{2}{c}{ To be productive } \\
\hline Scale & F & $\%$ & F & $\%$ & F & $\%$ & F & $\%$ & F & $\%$ \\
\hline Agree & 42 & 64.6 & 53 & 82.8 & 49 & 75.4 & 51 & 78.5 & 53 & 81.6 \\
Not sure & 9 & 13.8 & 5 & 7.8 & 7 & 10.8 & 6 & 9.2 & 8 & 12.3 \\
Disagree & 14 & 21.6 & 6 & 9.4 & 9 & 13.8 & 8 & 12.3 & 4 & 6.1 \\
\hline
\end{tabular}

From the above findings, $64.6 \%$ of management staff agrees cash bonuses motivate them to attend work regularly, $21.6 \%$ disagree and $13.8 \%$ were not sure. Majority of the respondents $82.8 \%$ agree cash bonuses motivate them to achieve objectives and targets, $9.4 \%$ disagree, and $7.8 \%$ were not sure. In respect to whether cash bonuses motivate employees to be timely in completing their duties, $75.4 \%$ agreed, $10.8 \%$ were not sure, while $13.8 \%$ disagreed. $78.5 \%$ agree that cash bonuses motivate them to do quality work, $9.2 \%$ were not sure and another $12.3 \%$ disagreed. Majority of the respondents $81.6 \%$ agree cash bonuses motivate them to be productive in their work, $12.3 \%$ were not sure while $6.1 \%$ disagreed.

The results show that majority of employees have a perception that cash bonuses motivate performance. Cash bonuses were perceived to have a great influence in motivating employees to achieve their targets as well as in motivating them to be more productive in their work; however it only has significant influence when it comes to motivating employee attendance.

This study sought to establish the effect of cash bonuses on employee performance. A chi square test was hence used to test the null hypothesis that there is no statistically significant effect of cash bonus and employee performance. The results are as shown in table below.

Table 2. Chi-square test for effect of cash bonuses on employee performance

\begin{tabular}{ccccc}
\hline \multirow{2}{*}{ Receive cash bonus } & \multicolumn{3}{c}{ Categorised mean cash bonus } & Total \\
\cline { 2 - 5 } & Low & Moderate & High & 8 \\
No & 0 & 2 & 6 & 55 \\
Yes & 1 & 10 & 44 & 63 \\
Total & 1 & 12 & 50 & 63 \\
\hline
\end{tabular}

$\left(X^{2}=0.338\right.$, d.f $\left.=2, p=0.8\right)$. 
The results in table 2 show that there is no relationship between cash bonuses and employee performance. Hence, there is no significant effect of cash bonus on employee performance $(p=0.8)$. This means those who receive cash bonuses and those who do not all agree that the cash bonus affects their performance the same. Therefore there is no statistically significant effect of cash bonuses on employee performance.

Cash bonuses are used to reward employees' performances during the year under appraisal, but there is also the unspoken expectation that these bonuses will be a factor in motivating employees' performance next year as well. This explains why there is no difference in perception of cash bonus in regards to performance for those employees who have received it and those who have not. Also employees who have received it once will want to get it the next year too, those who did not get will consider improving so that they can get it next time.

\section{Conclusions and Recommendations}

\subsection{Conclusion}

The study concluded that cash bonuses had no significant effect on employee performance. Those who had received and those who had not received perceived it to affect their performance the same; hence it did not have a significant effect on performance.

Garlick (2009) found that cash bonuses do not seem to impact much on performance, those who receive are just slightly more satisfied than those who get no reward. Cash bonuses had little impact on company performance. Cash bonuses only seem to make employees happy and to stop them from being dissatisfied, but they do not seem to have an impact on employees' performance.

\subsection{Recommendations}

Rewards have been known to have a positive effect on employee performance. However no reward system is perfect, this is because motivation is personal and what motivates one employee could be different from what motivates the next. Therefore, the organization should get to know their employees well so that they can employ the right motivational strategy.

Herz bergs motivator-hygiene theory says that if higher level needs were met like a sense of achievement, opportunities for personal growth and having responsibility were met, individuals would be motivated (Ryan \& Pointon, 2005). The organization should hence change the intrinsic nature and content of jobs by enriching them so as to enhance employees' sovereignty, opportunities for them to have additional responsibilities, gain recognition and develop their skills so that employees can achieve peak performance.

\subsection{Suggestions for Further Research}

This study did not focus on all the rewards, it only focused on cash bonuses. Further research can examine the effect of other rewards such as owning equity and whether it has an impact on performance.

Research can also be carried out to identify other factors which may affect performance but which have not been studied to determine their effect. Such findings can enhance management of performance.

\section{References}

Agarwal, N. C. (1998). Reward Systems: Emerging Trends \& Issues. Academic Journal Article: Canadian Psychology. Retrieved from http://findarticles.com

Ali, R., \& Ahmed, M. (2008). The Impact of Reward \& Recognition Programs on Employees Motivation \& Satisfaction. Retrieved from http://www.bizresearchpapers.com/22.Reena.pdf

Armstrong, M. (2006). A Handbook of Human Resource Management Practice (10th ed.). London: Kogan Page.

Axelsson, A., \& Bokedal, S. (2009). Reward Systems Motivating Different Generations. A Case study of Volvo $\mathrm{Car}$ Corporation. University of Gothenburg. Retrieved from http://gupea.ub.se/bitstream/2077/21241/1/gupea_2077_21241_1.pdf

Bartol, K. M., \& Locke, E. A. (2002). Incentives \& Motivation. San Francisco, CA: Lexington Press.

Bartol, K. M., \& Srivastava, A. (2002). Encouraging Knowledge Shairing: The Role of Organizational Reward Systems. Journal of Leadership \& Organizational Studies, 9(1). Sage Publications. Retrieved from http://jlo.sagepub.com

Block, R. H., \& Lagasse, D. R. (1997). Making a bonus plan work for you. HR Magazine, 1. Retrieved from http://findarticles.com

Bohlander, E., Snell, S., \& Sherman, A. (2001). Managing Human Resources (12th ed.). London: South Western College. 
Cole, G. A. (2002). Organizational Behaviour. London: Continuum.

Duberg, C., \& Mollen, M. (2010). Reward Systems within the Health and Geriatric Care Sector. Retrieved from http://gupea.ub.se/bitstream/2077/21241/1/gupea_2077_21241_1.pdf

Finkle, L. (2011). Motivating Employee Performance Through Year End Bonuses. Retrieved from http://ezinearticles.com/?Motivating-Employee-Performance-Through-Year-End-Bonuse\&id.5658825

Hakala, D. (2008). How to Measure Employee Performance, 16 Ways. HR World Newsletter. Retrieved from http://www.hrworld.com/features/16-ways-measure-perfromance-021908/

Hartman, J. E., Kurtz, M. E., \& Moser, K. E. (1994). Incentive Programs to Improve Transit Employee Performance. Washington D.C: National Academy Press. Retrieved from http://www.worldtransitresearch.info/research/2805/

Heathfield, S. M. (2000). Promotion is often a Reward to an Employee for work Contribution. Human Resource Guide Newsletter. Retrieved from http://humanresources.aboutcom/od/glossaryp/g/promotion.htm

Jamil, B., \& Raja, N. S. (2011). Impact of Compensation, Performance Evaluation and Promotion practices on Government Employees Vs Private Employees. Interdisciplinary Journal of Contemporary Research in Business, 3(8). Retrieved from http://www.journal-archieve13.webs.com/907-913.pdf

Jenkins, D., \& Lawler III, E. E. (1992). Strategic Reward Systems. California. Retrieved from http://ceo.usc.edu/pdf/T922205.pdf

Kiyoshi, T. (2006). Effects of Wage and Promotion Incentives on the motivational level of Japanese employees. Retrieved from http://www.kobe-u.ac.jp/repository/90000137.pdf

Kotelnikov, V. (2010). Reward Systems \& Reward Motivation (Effective Reward Systems: Increasing Performance \& Creating Happier Employees). Retrieved from http://www.1000ventures.com/business-guide/crosscuttings/motivating-reward-system.html

Kothari, C. R. (2004). Research Methodology Methods and Techniques (2nd ed.). New Delhi, New Age International.

Maund, L. (2001). An Introduction to Human Resource Management Theory \& Practice. Palgrave, Macmillan.

Morris, J. (2007). The Art of Employee Motivation. Retrieved from http://sourcesmaster.blogpot.com/2007/06/art-of-employee-motivation.html

Normand, B. (2010). How to design a good incentive plan. Retrieved from http://www.businessperform.com/articles/incentiveplandesign.html

Nzuve, S. N. M. (2007). Management of Human Resources: A Kenyan Perspective. Nairobi: Tech \& Pro Associates.

Peil, M. (1995). Research Methods: A Handbook for Africa (2nd ed.). Nairobi: East African Educational Publishers.

Prasetya, A., \& Kato, M. (2009). The effect of financial and non-financial compensation to the employee performance. Thesis, Asia Pacific University, Japan. Retrieved from http://www.studymode.com

Purkayastha, D., \& Chaudhari, A. (2011). Perfromance Management and Reward Systems. A case study of Scottrade Inc. IBS Center for management Research. Retrieved from http://www.ecch.com/educators/products/view?id=100368

Sarvadi, P. (2010). The Best Ways to Reward Employees. Entrepreneur Magazine. Retrieved from $\mathrm{http}: / / \mathrm{www} . e n t r e p r e n u e r . c o m / h u m a n r e s o u r c e s /$ article75340.html

Schoeffler, B. (2005). Employee Incentive Plans. Make them Worthwhile. Insurance Journal. Retrieved April 18, 2005, from http://www.insurancejournal.com/magazines/west/2005/04/18/features/54614.html

Thompson, C., \& Rampton, L. (2003). Human Resource Management. NewYork: Melbourne Press.

Torrington, D., Hall, L., \& Stephen, T. (2008). Human Resource Management (7th ed.). Edinburg: Pearson Education Limited.

Wilson, B. T. (2003). Innovative Reward Systems for the Changing Work Place. NewYork: McGraw Hill. Retrieved from http://books.google.co.ke/books?id=qRBSya4773AC

Yokoyama, M. (2007). When to use Employee Incentive Gifts. Retrieved from http://ezinearticles.com/?when-to-use.employee-incentive-gifts\&id=647448 


\section{Copyrights}

Copyright for this article is retained by the author(s), with first publication rights granted to the journal.

This is an open-access article distributed under the terms and conditions of the Creative Commons Attribution license (http://creativecommons.org/licenses/by/3.0/). 